\title{
Kršćanski identitet u otvorenosti drugima i drukčijima
}

\author{
David KOVAČEVIĆ* \\ UDK: 27-248.2-725.6 • Pregledni članak \\ Primljeno: 24. veljače 2016. P Prihvaćeno: 27. veljače 2017.
}

${ }^{*}$ Mr. sc. David Kovačević,

Visoko evanđeosko teološko učilište,

Cvjetkova 32, 31000 Osijek, Hrvatska, david. kovacevic.cog@gmail.

Sažetak: Cilj je ovoga rada ukazati na specifičnu izvorišnu točku kršćanskoga identiteta po kojoj je moguće autentično naviještati silna djela Božja. Ona je u osobi Isusa Krista koji kao pravi čovjek živi život za druge. Upravo ta stvarnost odnosa ja i ti treba biti ishodište kršćanskoga identiteta i odnosa prema drugima i drukčijima. Kršćanski je identitet danas u krizi jer se kršćanske zajednice uglavnom postavljaju obrambeno prema izazovima suvremenoga svijeta i na taj način gase prirodnu otvorenost Kristova evanđelja prema opterećenom svijetu. U ovome radu autor nastoji oslikati paradigmu prvotne kršćanske zajednice kako je ona predstavljena u Dj 2, 1-13. U tome biblijskom tekstu prvotna kršćanska zajednica svoje djelovanje prema drugima postavlja na temelju svojega identiteta koji je proizlazio iz njihova odnosa sa živim Isusom Kristom. To je vidljivo u sljedećim karakteristikama prvotne kršćanske zajednice: ona prije svega čeka na snagu odozgo, Duha Svetoga; shvaćanje potrebe za tom snagom je ujedinjuje, ona je okupljena zajedno; na nju je izlivena očekivana snaga Duha Svetoga po kojoj je ona opremljena za službu naviještanja; tako opremljena služi drugima i drukčijima, svim narodima pod nebom; otvorena je za specifične identitete drugih, no u toj otvorenosti ona ne gubi svoj identitet; ona nije zaokupljena sobom, nego navještajem o Bogu; i na kraju govor o Bogu ostaje poziv ponuden svima, bez prisile. Zajednica koja živi takav autentični kršćanski identitet postaje Božjim instrumentom $u$ ovome svijetu po kojem Bog svakom čovjeku na zemlji izražava svoju gostoljubivost.

Ključne riječi: identitet, drugi i drukčiji, Isus Krist, Pedesetnica, Duh Sveti, kršćanska zajednica. 


\section{Uvod}

Ovaj rad stavlja u središte pozornosti problematiku izazvanu strahom prema drugom i drukčijem koji je, nažalost, nerijetko prisutan u kršćanskim krugovima. Taj je strah očit pogledom u međukršćanske odnose, ali i odnose kršćana prema pripadnicima drugih religija, kultura i naroda.

Osnovna je tvrdnja ovoga rada kako je gore spomenuti strah posljedica egzistencije unutar neautentičnoga kršćanskoga identiteta. Autentičnost istoga otvara se pogledom u Isusa Krista koji svoju egzistenciju ostvaruje životom koji živi za druge i drukčije.

Rad je podijeljen na četiri susljedna dijela po kojima autor razvija temu kršćanskoga identiteta u otvorenosti prema drugima i drukčijima. Rad otpočinje analizom trenutačnoga stanja koje otvara pitanje krize kršćanskoga identiteta. Kriza kršćanskoga identiteta rezultat je odmicanja Crkve od svoga izvorišta koji se nalazi u Isusu Kristu i, posljedično tomu, zatvaranju u sebe. U Isusu Kristu otkrivamo iznenađujuću dinamiku autentičnoga kršćanskoga identiteta koji se živi u otvorenosti prema drugima i drukčijima. Primjer takve egzistencije možemo naći analizirajući život prve kršćanske zajednice. Otvarajući se za druge, prema primjeru Isusa Krista, prva kršćanska zajednica svoj identitet nije gubila, već ga je potvrđivala. Na samome kraju ovoga rada autor ističe poziv Crkve da se i danas živi autentičnim kršćanskim identitetom jer po njoj Bog svakome čovjeku na zemlji želi izraziti svoju gostoljubivost.

\section{Kriza kršćanskoga identiteta}

Pitanje kršćanskoga identiteta ili pitanje što znači biti kršćanin, odnosno s kim se kršćanin može i treba poistovjetiti, na nov se način otvara u svakom vremenu. Nikola Vranješ o kršćanskom identitetu u našem vremenu, i to i u širem, europskom kontekstu i u domaćem, hrvatskom kontekstu, govori kao o identitetu u krizi. ${ }^{1}$

Kriza kršćanskoga identiteta vidljiva je najprije u međusobnoj kršćanskoj razjedinjenosti. Civilizacija u kojoj živimo, civilizacija tehnoloških dostignuća, globalizacije i pluralizma, umorna je od religije, ali ne zato što je umorna od priče o Bogu, već zato što je umorna od načina života i neslaganja onih koji kažu kako u Boga vjeruju. Među ostalim, umorna je i od priče o kršćanstvu. Postoji priča o rabinu koji je gledao djecu kako se igraju skrivača. Gledajući djecu kako se igraju, rabin je počeo plakati. Djeca koja su se igrala prišla su mu i upitala ga: »Zašto plačete? « Rabin je odgovorio: »Plačem zato jer se i Bog skrio, ali nema nikoga tko bi

\footnotetext{
${ }^{1}$ Usp. N. VRANJEŠ, Identitet postmodernog čovjeka u europskom kontekstu i kršćanski identitet danas, u: A. POLEGUBIĆ (ur.), Zbornik radova: Kršćanstvo i identitet, Frankfurt, 2014., 35.
} 
ga tražio! $\ll^{2}$ Upravo zato što je narod Božji danas zanemario svoj istinski identitet, govor o Bogu, svijet oko njega ne traži odgovor u Bogu.

Dekret o ekumenizmu Unitatis Redintegratio II. vatikanskoga sabora u prvom odjeljku ističe: $\gg$ Ta razdijeljenost, dakako, otvoreno proturječi Kristovoj volji, na sablazan je svijetu i nanosi štetu najsvetijoj stvari: naviještanju evanđelja svemu stvorenju. $\ll^{3}$ Drugim riječima, nanosi štetu naviještanju silnih djela Božjih. Protestantske su Crkve vrlo rano uočile problem razdijeljenosti među kršćanima kao uteg koji opterećuje naviještanje evanđelja svijetu. Aktivno zauzimanje za jedinstvo kršćana među reformacijskim Crkvama bilježimo još 1910. godine kada se o tome problemu govorilo na međunarodnoj misijskoj konferenciji u Edinburghu. ${ }^{4}$ Godine 1974. u Lausanneu održana je važna konferencija na kojoj su uloženi značajni napori reformacijskih Crkava prema snažnijem jedinstvu. Zaključeno je kako je jedinstvo dar Božji po Svetome Duhu, a moguće je zbog Kristove otkupljujuće žrtve na križu. Vidljivo jedinstvo Crkve važno je zbog svjedočanstva svijetu. Kako djelovati u službi pomirenja ako Crkve među sobom nisu izmirene? ${ }^{5}$

Time se otvara druga razina na kojoj je vidljiva kriza kršćanskoga identiteta, a ona je u odnosu kršćana, općenito, prema narodima drugih religija i narodnosti. Taj je problem vidljiv i u hrvatskom kontekstu. Kako se hrvatsko društvo odnosi prema drugima i drukčijima? Jedan od svježijih primjera jest izbjeglička kriza u kojoj su se zbog rata u Siriji, Iraku i Afganistanu više milijuna ljudi odlučilo sigurniji i bolji život potražiti u Europi. Ta kriza eskalirala je 2015. godine kada su stotine tisuća ljudi prošli i kroz Hrvatsku. Reakcije su bile izmiješane: od nervoze, straha, prijetnje i poziva na podizanje žice; do raširenih ruku, suosjećanja i gradnje izbjegličkih tranzitnih centara u Opatovcu i Slavonskom Brodu. Vidliiva je velika podijeljenost hrvatskoga društva u svezi s drugima i drukčijima. Nažalost, velik broj građana reagirao je sa sumnjom, kao da do sada nije imao iskustvo suživota s drugima i drukčijima. Mnogi su se uplašili i pripadnosti velikoga broja izbjeglica islamskoj vjeroispovijesti kao da u Hrvatskoj već nemamo sugrađane islamske vjeroispovijesti, ali i drugih konfesija kao što je Pravoslavna Crkva, židovska zajednica, pa i različite reformacijske Crkve.

Frano Prcela u svome članku Polog katoličkoga u hrvatskom identitetu iznosi neke od problema s kojima se religija susreće u hrvatskom društvu. Hrvatsko je druš-

\footnotetext{
${ }^{2}$ M. PARLOV, Budni budite. Teološka meditacija za došašće i Božić, Zagreb, 2005., 23.

${ }^{3}$ DRUGI VATIKANSKI KONCIL, Unitatis redintegratio. Dekret o ekumenizmu (21. XI. 1964.), br. 1, u: Dokumenti, Zagreb, 2008.

${ }^{4}$ Usp. D. HORTON (ur.), The Portable Seminary, Minnesota, 2006., 539.-542.

${ }^{5}$ Usp. isto.
} 
tvo još uvijek tranzicijsko. Religija se u nas ne snalazi dobro u procesima kao što su demokracija i pluralizam. ${ }^{6}$ Ona svoju energiju uglavnom troši na pozicioniranje u društvu, ne stavljajući tako pravi naglasak na odgoj i edukaciju svojih vjernika. ${ }^{7}$ Uzrok je tomu nerazumijevanje demokratskih i pluralističkih procesa koji su prilika slobodnoga govora za svakoga pojedinca. Takav govor nije prijetnja, već prilika za afirmaciju religije koja treba promicati kulturu slobodnoga dijaloga. Ona ne treba nositi breme pozicioniranja, već svjedočanstvima svojih vjernika u javnom životu može graditi autoritet $u$ društvu. ${ }^{8}$

Pluralistički kontekst ne bi trebao biti stran za Crkvu jer se zajednica prvih kršćana razvijala u sličnom kontekstu. Uzmimo u obzir židovsko izvorište Crkve, širenje po helenističkom i rimskom svijetu, uspostavu Crkve u jugoistočnoj Indiji, Etiopiji itd. ${ }^{9}$

Tonči Matulić u svome članku Identitet i hrvatski identitet kao metafizičko-antropološki problem uočava važnost izgradnje vjernika laika koji će autentično živjeti vjeru u demokratskom i pluralističkom kontekstu. Naše doba Matulić naziva dobom autentičnosti! Emancipacija pojedinca prilika je za izgradnju novoga gledanja na obranu identiteta tako što će se ta obrana odmaknuti od tradicionalnih autoriteta, institucija i dati je pojedincu. ${ }^{10} \mathrm{Na}$ taj način Matulić raspravu o identitetu vidi kao raspravu o identitetu u odnosu jedinstva i mnoštva u mijenama povijesnih okolnosti. ${ }^{11}$

\section{Krist - čovjek za druge - izvor autentičnoga kršćanskoga identiteta}

Krizu kršćanskoga identiteta moguće je nadvladati onoliko koliko se vraćamo izvorištu kršćanske vjere: Isusu Kristu. Kršćanski identitet proizlazi iz Krista i on se živi za Krista. On je izvor i uzor kršćanske egzistencije. U 1 Pt 2, 4-5 o tome čitamo sljedeće: »Pristupite k njemu, Kamenu živomu što ga, istina, ljudi odbaciše, ali je u očima Božjim izabran, dragocjen, pa se kao živo kamenje ugrađujte u duhovni Dom za sveto svećenstvo da prinosite žrtve duhovne, ugodne Bogu po Isusu Kristu.« Nadalje u 1 Pt 2, 6 čitamo: »Evo postavljam na Sionu kamen odabrani, dragocjeni kamen ugaoni: Tko u nj vjeruje, ne, neće se postidjeti.« Nikola Vranješ naglašava

\footnotetext{
${ }^{6}$ Usp. F. PRCELA, Polog katoličkoga u hrvatskom identitetu, u: Z. LUKIĆ, B. SKOKO (ur.), Zbornik radova Matice Hrvatske: Hrvatski identitet, Zagreb, 2009., 226.

${ }^{7}$ Usp. isto, 223.

${ }^{8}$ Usp. isto, 226.-228.

${ }^{9}$ Usp. A. E. McGRATH, Uvod u kršćansku teologiju, Zagreb - Rijeka, 2006., 509.

${ }^{10}$ Usp. T. MATULIĆ, Identitet i hrvatski identitet kao metafizičko-antropološki problem, u: Z. LUKIĆ, B. SKOKO (ur.), Zbornik radova Matice Hrvatske: Hrvatski identitet, 80.-81.

${ }^{11}$ Usp. isto, 82.
} 
kako kršćanski identitet proizlazi iz odnosa s Isusom Kristom. Krist je izvorište kršćanskoga identiteta, a čovjek ga prima kao dar. Susret s Isusom Kristom utječe na cjelovitost života ljudske osobe. ${ }^{12}$

Na susretu međunarodne razine u Ženevi 1949. godine Karl Barth bio je pozvan progovoriti o novom humanizmu s kršćanskoga gledišta i suvremenosti kršćanske poruke o tome. Naglasio je svoju začuđenost pozivom sekularnih stručnjaka da kao teolog s kršćanskoga gledišta progovori o čovjeku u modernom dobu, dobu koje s nepovjerenjem pristupa kršćanskoj teologiji i pitanjima o Bogu. U svome izlaganju Barth je naglasio kako je s kršćanskoga gledišta o čovjeku moguće govoriti tek s gledišta Božjega humanizma i to s obzirom na specifičnu povijesnu točku: život Isusa Krista! ${ }^{13}$ Čovjeka se s kršćanskoga stajališta može razumjeti s gledišta utjelovljene Riječi, gdje je Bog u Isusu Kristu postao čovjek. Tako u zrcalu Isusa Krista čovjek može promatrati svoj istinski identitet jer gleda u onoga na čiju je sliku stvoren. ${ }^{14}$

U Isusu Kristu vidimo pravoga čovjeka koji svoj puni potencijal i autentični identitet postiže tako što život živi za drugoga čovjeka u odnosu ja i ti. Bez toga odnosa nema čovjeka. Iz toga proizlazi kako je Isus čovjek za druge. Kršćanin ne može promatrati Boga, čovjeka, međusobni odnos Boga i čovjeka, međusobni odnos čovjeka i čovjeka bez pogleda u Isusa Krista. ${ }^{15}$ Što otkrivamo gledajući u Krista? Svrha Njegova dolaska u svijet bila je za druge. On je živio život za druge, posebice za one u najvećoj potrebi: za siromašne, zarobljene, potlačene, ljude u tami i, općenito, opterećene raznim bremenima života (Lk 4, 18-19 ili Iz 61, 1-2). Na kraju, umro je radi drugih. Kršćanska vjeroispovijest kaže kako On i danas živi zastupajući druge (1 Iv 2, 1). Valja zaključiti kako je u svojoj naravi Krist čovjek koji život živi za druge.

Takav kršćanski humanizam; ili Božji humanizam; treba postaviti prema individualističkim i kolektivističkim humanizmima. Božji humanizam proširuje vidike individualizma jer pojedinca postavlja u suodnos s drugim pojedincem. Također, on proširuje i vidike kolektivizma jer ukazuje na zajednicu koja je odgovorna prema svim pojedinim građanima, uključujući slobodu i odgovornosti svakoga od njih. Takav humanizam $\gg$ štiti svezu, nasuprot Nietzscheu, i slobodu nasuprot Marxu ${ }^{16}$. Tako Barth vidi istinsku bit čovjeka kao kontinuirani prosvjed protiv nepravde i

\footnotetext{
${ }^{12}$ Usp. N. VRANJEŠ, Identitet postmodernog čovjeka u europskom kontekstu i kršćanski identitet danas, 31.-33.

${ }^{13}$ Usp. K. BARTH, Suvremenost kršćanske poruke, u: K. BARTH, Teološki eseji, Rijeka, 2008., 7.-8.

${ }^{14}$ Usp. isto, 9.

${ }^{15}$ Usp. isto, 12.

${ }^{16}$ Isto, 13.
} 
čovjeka kao slobodnu individuu u suodnosu i odgovornosti prema drugom i drukčijem, i Bogu i čovjeku. ${ }^{17}$

\section{Zajednica prvih kršćana potvrđivala je svoj identitet u Kristu otvarajući se drugima i drukčijima}

Promatrajući čovjeka našega vremena, mogli bismo pomisliti kako je Kristov primjer nedostižan ideal. Naime, većina energije koju čovjek ima vrti se uglavnom oko njega samoga i njegovih sebičnih interesa. Ipak, pogled u život prvotne kršćanske zajednice u prvome stoljeću svjedoči kako je snagom Duha moguće živjeti po Kristovu primjeru. Spomenuvši kontekst zajednice prvih kršćana ili prvoga stoljeća, donijet ćemo kratku analizu novozavjetnoga primjera koji svjedoči o njihovu autentičnom životu i djelovanju. Riječ je o biblijskom tekstu iz $\mathrm{Dj} 2$, 1-13 zajedno s njegovim bližim kontekstom. Taj primjer prikazat će način na koji su prvi kršćani svoje djelovanje prema drugima gradili na temelju svojega identiteta koji je proizlazio iz njihova odnosa sa živim Isusom Kristom.

Prije svega valja reći kako se knjiga Djela apostolskih ne odnosi na nekakvu novu priču koja bi bila drukčija od priče koja je započela s Isusom. Sve što nalazimo u knjizi Djela apostolskih u stvarnosti je nastavak onoga što je Isus započeo. Crkva ne radi nešto drugo od onoga što je Isus činio. Ako je Isus bio čovjek za druge, i Crkva treba biti zajednica za druge! ${ }^{18}$ Božja snaga, očitovana po uskrsnuću i Isusovu uzašašću, izlivena je na Božji narod na Pentekost. ${ }^{19}$ Ista snaga po kojoj je Isus začet, po kojoj je živio, po kojoj je uskrsnuo i otišao Ocu izlivena je na Crkvu. Ono što je značajno uočiti jest da priča koju je započeo Isus, a Crkva u Djelima apostolskim nastavila, nije završila ni zadnjom stranicom Djela apostolskih. Ona se nastavlja danas po onima koji nastavljaju živjeti poput Isusa i ispunjavati njegove zapovijedi.

\subsection{Zajednica onih Koji ČEKaju Na Boga (DJ 1,4$)$}

Prethodno ulomku iz Dj 2, 1-13 čitamo o Kristovim učenicima koji u Jeruzalemu čekaju »obećanje Očevo « ili izlijevanje Duha Svetoga, kako ih je Isus uputio nakon svoga uskrsnuća: $\gg I$ dok je jednom s njima blagovao, zapovijedi im da ne napuštaju Jeruzalema, nego neka čekaju obećanje Očevo.« (Dj 1,4) Zajednica prvih kršćana tako je najprije zajednica onih koji čekaju. Tu nije riječ o ljudima koji sjede u udobnom uredu i dane provode razmišljajući i pišući projekte o tome »kako najbolje u

\footnotetext{
${ }^{17}$ Usp. isto, 12.-13.

${ }^{18}$ Usp. W. BARCLAY, The Daily Study Bible Series/The Acts of the Apostles, Philadelphia, 1976., 9.

${ }^{19}$ Usp. W. H. WILLIMON, Interpretation. A Bible Commentary for Teaching and Preaching. Acts, Louisville, 1988., 28.
} 
našem vremenu naviještati silna djela Božja našem užurbanom društvu. Mi bismo radije požurivali jedni druge što prije krenuti na posao jer zadaci koji su pred nama ne mogu više čekati!

Pravo je pitanje što je to čekala zajednica prvih kršćana. Čekala je primiti snagu bez koje ni u kojem slučaju ne bi mogla ispuniti svoje poslanje. Riječ je o Duhu Svetom, Životvorcu, onome koji je još u vrijeme stvaranja (Post 1,2) lebdio nad vodama kako bi iz kaosa dozvao stvari u red. To je njegov zadataki danas jer je i naše društvo više u kaosu nego u božanskom redu. Božji narod pozvan je biti svjetlo koje svijetli u tami (1 Pt 2, 9). Svijetliti može jedino ispunjen »obećanjem Očevim«.

\subsection{Okupljena Zajednica (Dj 2, 1)}

Radeći paralelu, možemo uočiti kako je Crkva koja u Dj 1, 4 čeka na Boga Crkva koja je u Dj 2, 1 okupljena zajedno: »Kad je napokon došao dan Pedesetnice, svi su bili zajedno na istome mjestu.« Što je temeljni razlog njihova jedinstva? To je jasna spoznaja kako je djelo koje trebaju činiti, naviještati silna djela Božja, nemoguće bez Boga, bez ispunjenja snagom odozgo, bez božanskoga izvora, tj. Duha Svetoga. Zajednica prvih kršćana tako je zajednica koja jedinstvo ostvaruje po božanskom izvoru, odakle joj dolazi sva pomoć. Ona nije zajednica koja je ustanovljena ljudskim naporima, stoga u svojim zadatcima ni ne može računati jedino na ljudske resurse ako želi ostati vjerna svome pozivu i poslanju. Crkva tako nije zajednica koja pasivno čeka, nego se okuplja s drugim udovima Kristova tijela aktivno tražeći i očekujući Božje pohođenje.

\subsection{Zajednica u kojoj Je Po Duhu Svetom nazočan Živi GOSPODIN Isus KRIST (DJ 2, 2-4)}

Kada je Crkva ujedinjena u svojoj slabosti i ovisnosti pred Gospodinom, blagoslovi je ne će zaobići. U njoj vidimo na djelu živoga Gospodina Isusa Krista koji po svome Duhu osposobljava kršćane za službu drugima: »I eto iznenada šuma s neba, kao kad se digne silan vjetar. Ispuni svu kuću u kojoj su bili. I pokažu im se kao neki ognjeni razdijeljeni jezici te siđe po jedan na svakoga od njih. Svi se napuniše Duha Svetoga i počeše govoriti drugim jezicima, kako im već Duh davaše zboriti.« $(\mathrm{Dj}$ $2,2-4)$

\subsection{ZAJEDNICA KOJA JE VJERNA SVOM IDENTITETU U KRISTU I ŽIVI ZA DRUGE LJUDE OKO SEBE (DJ 2, 5 I 9-11)}

Božje pohođenje dogodilo se tijekom blagdana Pedesetnice kada su se u Jeruzalemu okupili Židovi iz svih naroda pod nebom: »A u Jeruzalemu su boravili Židovi, ljudi pobožni iz svakog naroda pod nebom.« (Dj 2, 5) Po Duhu Svetom zajedni- 
ca prvih kršćana usmjerena je primljeni dar podijeliti s tom naglašeno raznolikom skupinom.

Uočimo raznolikost naroda kojima je poslana zajednica prvih kršćana: »Parti, Međani, Elamljani, žitelji Mezopotamije, Judeje i Kapadocije, Ponta i Azije, Frigije i Pamfilije, Egipta i krajeva libijskih oko Cirene, pridošlice Rimljani, Židovi i sljedbenici, Krećani i Arapi ... « (Dj 2, 9-11) Luka se ovdje koristi stilskom figurom liste naroda. ${ }^{20}$ Lukina lista različitih naroda iz kojih ti Židovi dolaze ukazuje na to koliko je Luki važno ukazati na globalni značaj onoga što opisuje. Božja poruka nije samo za neke, ona nije samo za Židove. Luka to izražava dajući značajnu sliku: »svi narodi pod nebom.« (Dj 2, 5) Ti elementi ukazuju kako se u Jeruzalemu nalazila internacionalna skupina. ${ }^{21}$ Ta otvorenost naglašena je i prema razlikovanju Židova koji dolaze iz svih naroda pod nebom s jedne strane i skupine prozelita ili obraćenika na židovstvo koji po narodnosti nisu bili Židovi s druge strane (Dj 2, 10).

Božji blagoslovi i sebedarje usmjereno je svim ljudima. Nitko nema niti može imati monopol nad Božjim blagoslovima. To je naglašeno frazom: $\gg$ sve narode pod nebom. «Svaki etnicitet, svaki jezik, svaki narod, svaka kultura može i treba imati udio u Božjim blagoslovima za svijet. Događaj Duha nije namijenjen isključivo osobnoj pobožnosti vjernika niti ga je moguće privatizirati. Bio je popraćen takvom bukom koja je privukla okupljen narod. Događaj Duha javan je događaj. ${ }^{22}$

\subsection{ZAJEDNICA KOJA JE OTVORENA ZA SPECIFIČNE IDENTITETE DRUGIH, ALI U TOJ OTVORENOSTI NE GUBI SVOJ VLASTITI IDENTITET (DJ 2, 6-8)}

Duh Sveti sišao je na Isusove učenike i počeli su govoriti materinskim jezicima onih koji su se iz različitih naroda okupili u Jeruzalem na blagdan Pedesetnice. Okupljeni su u čudu govorili: »Gle! Nisu li svi ovi što govore Galilejci? Pa kako to da ih svatko od nas čuje na svojem materinjem jeziku? « (Dj 2,7-8) Bog je na taj način, po Crkvi kao predanom sredstvu, prilagodio svoju Riječ onima kojima je izlazio u susret.

U tome procesu otvorenosti za druge i drukčije zajednica prvih kršćana nije izgubila svoj identitet, naprotiv, potvrdila ga je. Slušajući ih kako govore njihovim materinskim jezicima, okupljeni su ljudi uočili njihov galilejski dijalekt. Na sličan način, slušajući govornike engleskoga jezika, i danas možemo po njihovu naglasku prepoznati dolaze li primjerice iz Rusije ili Afrike. Bog je zajednicu prvih kršćana

${ }^{20}$ Usp. D. J. HARRINGTON (ur.), Sacra Pagina. Luke Timothy Johnson, The Acts of the Apostles, Collegeville, Minnesota, 1992., 45.

${ }^{21}$ Usp. L. E. KECK (ur.), The New Interpreter's Bible. Commentary in Twelve Volumes. Volume X. Acts, Introduction to Epistolary Literature, Romans, 1 Corintihians, Nashville, 2002., 56.

${ }^{22}$ Usp. isto, 57. 
blagoslovio darom govora drugih jezika ne umanjujući njihov autentični identitet, već koristeći se njime.

\subsection{ZaJednicA KOJA NE NAVIJEŠTA SVOJA, VEĆ SILNA DJELA BožJA (DJ 2, 11)}

U 11. retku nazire se vrhunac toga događaja. Ne samo da ih ljudi iz svih naroda slušaju na svojim materinskim jezicima nego i u njihovu naviještaju razabiru govor o silnim djelima Božjim: »Svi ih mi čujemo gdje našim jezicima razglašuju veličanstvena djela Božja,« (Dj 2,11) Ti ljudi nisu privučeni time što Galilejci govore njihovim jezicima, već sadržajem njihova govora. Zajednica prvih kršćana nije govorila o svojoj kolekciji poštanskih markica. Nisu govorili o sebi i svojim naučavanjima. Govorili su o silnim djelima Božjim. Drugim riječima, govor o Bogu sadržaj je koji privlači ljude iz svih naroda pod nebom. Narodi nisu privučeni sjajem određene kulture, već Bogom koji prihvaća različite kulture, Bogom koji prihvaća drugoga i drukčijega. Ljudi oko nas ne će biti privučeni našim dobro razrađenim naukom. Ljudi će biti privučeni navještajem čiji sadržaj govori o živome Bogu koji se otvara za svako biće pod nebom.

Naviještanje silnih djela Božjih ili Riječi Božje u Novom zavjetu vezano je uz ispunjavanje Duhom. Duhom ispunjeni pojedinci govore Riječ Božju na opću korist tijela Kristova i ostalih ljudi koji tek trebaju doći u susret s događajem Isusa Krista.

Taj obrazac moguće je pratiti upravo u Lukinu korpusu, i u evanđelju i u Djelima apostolskim. Na samome početku Evanđelja Mesijin preteča, onaj koji je trebao navijestiti dolazak Božjega Pomazanika, Ivan Krstitelj postaje ispunjen Duhom (Lk 1, 15). Sam Pomazanik začet je u utrobi svoje majke Marije po Duhu Svetom (Lk 1,35). Ivanova majka Elizabeta (Lk 1, 41-42) i otac Zaharija govore Riječ Božju po Duhu Svetom $(L k 1,67)$. Starac Šimun po Duhu Svetome izgovara proročke Riječi koje se u Mesiji trebaju ispuniti (Lk 2, 25-32). I proročica Ana pripada u tu kategoriju (Lk 2, 36). Isus u svome prvom nastupu u nazaretskoj sinagogi izgovara riječi pun Duha Svetoga $(\mathrm{Lk} 4,1)$. U istoj toj snazi i prvi će učenici moći ispuniti svoje poslanje. To je ono o čemu piše Luka u Djelima apostolskim u prvome i drugome poglavlju. Učenici postaju ispunjeni Duhom Svetim i Židovi iz svih naroda pod nebom čuju ih na svome jeziku kako govore o silnim djelima Božjim (Dj 2, 11). Prva Petrova propovijed, po Pedesetnici, izgovorena je u snazi Duha ( $\mathrm{Dj} 2,33){ }^{23}$

${ }^{23}$ Usp. J. B. POLHILL, The New American Commentary. An Exegetical and Theological Exposition of Holy Scripture. Acts, Nahville, Tennessee, 1992., 95.-96. 


\subsection{NJEZIN GOVOR JE OTVOREN, ON NIKOGA NE PRISILJAVA, SVATKO TKO SLUŠA IMA PRAVO IZBORA (DJ 2, 12-13)}

Okupljene u Jeruzalemu nalazimo privučene govorom o silnim djelima Božjim. Ipak, još uvijek svatko ima mogućnost izbora hoće li za takvim Bogom poći ili će ostati zatvoren u sebi: »Svi su izvan sebe zbunjeno jedan drugog pitali: ‘Što bi to moglo biti?' Drugi su pak, podrugujući se, govorili: Slatkog su se vina ponapili.« (Dj 2, 12-13) Jure Zečević jest istaknuo: »Vršeći svoje poslanje navještaja i djelujući u javnosti kršćani ne smiju zaboraviti da autentični navještaj Boga u Duhu Isusa Krista nije nametljiv i nasilan, da on uvijek ostaje ponuda i poštuje čovjekovu slobodu izbora onako kako je poštuje i sam Bog, koji bez pridržaja omogućava čovjeku, i po slobodi bogolikom, da i Njemu samom može reći 'ne': 'K svojima dođe i njegovi ga ne primiše.' (Iv 1,11$) \ll^{24}$

\section{Božji je naum kroz Crkvu izraziti gostoljubivost svakom čovjeku na zemlji}

Različiti teolozi, pogotovo reformacijsko-pentekostne baštine, bavili su se tim tekstom i fenomenom govora $u$ drugim jezicima ili na grčkom eterais glossais. ${ }^{25}$ Navest ću primjer Daniele C. Augustine, profesorice pri Lee sveučilištu u Clevelandu, Tennesee, u Sjedinjenim Američkim Državama.

U događaju Pedesetnice ili Pentekosta Augustine prije svega uočava Boga na djelu. U tome primjeru Bog djeluje pokazujući svoju otvorenost za druge i drukčije prilagođavajući svoju Riječ jezicima različitih etničkih skupina. Svoje djelo Bog ostvaruje po Crkvi koja je po Duhu produžetak Kristova tijela na zemlji. ${ }^{26}$ Božji pristup prema drugima nije tek retorika kojom bi kolonizirao druge. Govoreći jezik drugoga, Bog iskazuje gostoljubivost prilagođavajući sebe drugome i pozivajući ga u odnos međusobnoga poštovanja. ${ }^{27}$

Taj događaj ukazuje na to kako naše različitosti nisu puka slučajnost. U Knjizi Postanka u prvom poglavlju čitamo o tome kako Bog stvara svijet različitosti ili pluralnosti. Sve je stvorio po $\gg$ svojoj vrsti «, i različito bilje i razna životinjska bića (Post 1, 11 i 24-25). Tako razumijemo kako je egzistencija u različitosti dio Božjega originalnoga plana. Živjeti u svijetu različitosti ne znači živjeti bez jedinstva. U Kol 1, 17

\footnotetext{
${ }^{24}$ J. ZEČEVIĆ (ur.), Pozvani naviještati silna djela Gospodnja, Zagreb, 2015., 11.

${ }^{25}$ Primjerice postoji serijal publikacija naslovljenih »Pentecostal Manifestos« koje zajedno uređuju James K. A. Smith (pri Calvin College) i Amos Yong (Regent University School of Divinity).

${ }^{26}$ Usp. D. C. AUGUSTINE, Pentecost, Hospitality, and Transfiguration, Cleveland, 2012., 65.

${ }^{27}$ Usp. isto.
} 
čitamo o tome kako se sve što je stvoreno zajedno drži u Kristu. Drugim riječima, sve što postoji svoje izvorište ima u božanskoj realnosti. ${ }^{28}$

Na Pedesetnicu svaki narod na svome jeziku sluša istu priču o silnim djelima Božjim. Božji poziv različitim ljudima da se nađu zajedno u njegovu božanskom životu ne umanjuje niti razvodnjava njihove različitosti. ${ }^{29}$

Imajući u vidu taj biblijski sadržaj iz $\mathrm{Dj}$ 2, 1-13 i temeljne teološke zaključke koji govore o Crkvi kao zajednici otvorenoj za druge i drukčije, a na temelju svojega identiteta koji se nalazi u Kristu po Duhu Svetome, uzmimo u obzir i zaključke Miroslava Volfa koji je u svome djelu Isključenje i zagrljaj progovorio s teološkoga gledišta o identitetu, drugome i pomirenju, i to u kontekstu ratnih zbivanja na našim prostorima.

Središnja misao Volfa jest: $\gg$ Voljnost da sebe damo drugima i da ih 'zagrlimo', da prilagodimo svoj identitet tako da napravimo mjesta za njih, prethodi svakom sudu o drugima, osim suda kojim ih identificiramo kao ljudska bića. ${ }^{30}$ Zašto bismo sebe i svoj identitet na takav način otvarali za druge? Volf tvrdi kako naša spremnost prihvatiti drugoga proizlazi iz Božje spremnosti prihvatiti nas, i to kao od njega otuđena bića. Volf se za to koristi metaforom zagrljaja, odnosno Božjih ruku koje su raširene prema nama. Kao primjer navodi Kristove ruke s križa ispružene prema grješnicima i raširene ruke Oca koji dočekuje izgubljenoga sina! ${ }^{31}$ Drugim riječima, Bog nas ne prihvaća zato što mi prihvaćamo njega, već nas prihvaća prethodno našem otvaranju za njega. Središnji tekst kojim se Volf ovdje koristi kao mišlju vodiljom jest Rim 15, 7: »Primajte jedini druge u svoje društvo kao što je i Krist vas primio. $\ll^{32}$ Kristov odnos prema nama treba biti pokretač našega odnosa prema drugima i drukčijima. To je središte kršćanskoga identiteta: Bog u Isusu Kristu grli čovjeka otuđenoga od njega.

Otvorenost za drugoga na takav način nije bez cijene. Otvarajući svoje ruke u Isusu Kristu za one koji su otuđeni od njega, Bog se otvorio biti ranjiv. Prihvaćanje drugoga nikada ne može ići bez rizika. Bog je u Isusu Kristu bio spreman na taj rizik i do same smrti. Promatrajući globalizacijske trendove i prožimanje različitih identiteta po njima, mnogi su zabrinuti za opstanak pojedinačnih identiteta. Primjerice,

\footnotetext{
${ }^{28}$ Usp. W. A. DYRNESS, V.-M. KARKKAINEN (ur.), Global Dictionary of Theology, Downers Grove, 2008., 583.

${ }^{29}$ Usp. D. C. AUGUSTINE, Pentecost, Hospitality, and Transfiguration, str. 66.

${ }^{30}$ M. VOLF, Isključenje i zagrljaj, Zagreb, 1998., 31.

${ }^{31}$ Usp. isto.

${ }^{32}$ Usp. isto.
} 
Davorin Rudolf govori o ugroženosti manjinskih identiteta u kontekstu globalizacije ili, konkretno, u Europskoj uniji. ${ }^{33}$

Gledajući u one drukčije od nas, možda se ne ćemo složiti sa svim njihovim stavovima, ali u njima trebamo vidjeti priliku za vlastito bogaćenje. Oscar Cullmann pristupa ekumenizmu s gledišta $\gg j$ jedinstva u različitosti «, odnosno prepoznavanja kako različite kršćanske Crkve u sebi imaju određene karizme povjerene im na čuvanje. Svaka kršćanska Crkva u onoj drugoj treba uočiti pozitivne aspekte po kojima se i sama može bogatiti. ${ }^{34} \mathrm{U}$ Katoličkoj Crkvi Cullmann uočava karizme univerzalizma i institucije; u Crkvama reformacijske baštine usredotočenost na Sveto pismo i kršćansku slobodu koja favorizira otvorenost svijetu; dok za Pravoslavnu Crkvu kao karizme ističe teološku produbljenost u poznavanju Duha Svetoga te tradicionalne liturgijske forme. ${ }^{35}$

Problem koji se može javiti uslijed straha prema drugom i drukčijem jest oblikovanje vlastitoga identiteta s obzirom na one elemente koji nas razlikuju od drugih. $\mathrm{Na}$ taj problem upozoravaju Salim Munayer i Lisa Loden. Oni naznačuju kako je iznimno važno čuvati svoj identitet, ali kada naš identitet postaje zapreka zajedništvu s drugima i drukčijima, onda više nismo na Kristovu putu. ${ }^{36}$ Kao primjer navode biblijski tekst iz poslanice apostola Pavla Gal 3, 28. Susret Pavla s božanskom realnosti, objavljenoj u Isusu Kristu, tako je osvijetlila njegov identitet da ono po čemu se on razlikuje od drugih nije više bilo prepreka zajedništvu s drugim ljudima. ${ }^{37}$

Kršćanska Crkva ne gradi svoj identitet suprotstavljajući se drugima, već afirmativno, gledajući u Krista, onoga koji je živio za druge! »Budući da je ono što kršćane povezuje veće od onoga što ih razdvaja, onda je ne samo primjerenije nego i točnije druge kršćane opisivati i nazivati po onome što je veće (jedinstvo), nego li po onome što je manje (razdvojenost) i to treba zaživjeti i u praksi na svim razinama.« ${ }^{38}$

Valja razumjeti i u potpunosti prihvatiti Gospodina Isusa Krista kao snagu dostatnu za prevladavanje svih naših razlika i neprijateljstva. Ipak, snagu njegova života treba tražiti i u svoj identitet ugrađivati, tako ni autentično zajedništvo u Duhu Isusa Krista ne će izostati. Govoreći jezik drugih, učenici unutar svoga identiteta otvaraju

\footnotetext{
${ }^{33}$ Usp. D. RUDOLF, Identitet naroda i Europska unija, u: Z. LUKIĆ, B. SKOKO (ur.), Zbornik radova Matice Hrvatske: Hrvatski identitet, 111.-115.

${ }^{34}$ Usp. I. MACUT, Ograničenja i novosti II. vatikanskog sabora prema Oscaru Cullmannu, u: Služba Božja 51(2011.)1., 59.-60.

${ }^{35}$ Usp. isto.

${ }^{36}$ Usp. S. MUNAYER, L. LODEN, Through My Enemy's Eyes, Milton Keynes, 2014., 205.-206.

${ }^{37}$ Usp. isto, 208.-209.

${ }^{38}$ J. ZEČEVIĆ, Katoličko razumijevanje jedinstva i zajedništva kršćana, u: Kairos 2(2008.)1, 89.
} 
mjesto za druge. To otvaranje nije bilo bez rizika. Mnogi su ih ismijavali, a mnogi će im se kasnije otvoreno i nasilno suprotstaviti kao što su se suprotstavili i njihovu Učitelju. Ipak, mnogi će u njihovu govoru prepoznati onoga zbog kojega njihova egzistencija ima smisla, u njihovu govoru mnogi će prepoznati velika i silna djela Božja. Na kraju, njihovo djelovanje ne će biti na njihovu štetu. Ljudi koji su slušali učenike u njihovu dijalektu prepoznaju ljude iz Galileje. To znači da prilagođavanje svoga identiteta drugima i drukčijima ne znači i gubitak vlastitoga identiteta.

Takvo djelovanje proizlazi iz jasno usidrenoga identiteta u stvarnosti Isusa Krista koji je živio svoj život za druge i drukčije, prilagodio je svoju egzistenciju drugima i drukčijima, a ipak nije prestao biti ono što je oduvijek bio.

\section{Zaključak}

Kriza je kršćanskoga identiteta očita u kršćanskoj razjedinjenosti. Ta je razjedinjenost vidljiva u našem hladnom odnosu prema onima koji su donekle drukčiji od nas, od naše subraće kršćana. Ta se netrpeljivost dalje prelijeva i prema svijetu koji je dublje drukčiji od nas, to je svijet drugih religija i drugih naroda.

Krizu kršćanskoga identiteta moguće je prevladati onoliko koliko se vraćamo izvorištu kršćanske vjere koja svoj temelj ima u Isusu Kristu. Pogledom u Isusa Krista otkrivamo autentičan kršćanski identitet koji se ostvaruje u otvorenosti za druge i drukčije od nas.

Ipak, postoji opasnost da ta otvorenost drugima i drukčijima ostane samo puki ideal ako Crkva snagu ne crpi iz riznice Duha. Ta je opasnost posebno aktualna u svijetu usredotočenom na ispunjavanje potreba pojedinaca bez pravoga osvrta na njegovu odgovornost prema zajednici.

Upravo kada Crkva shvati svoju ovisnost o snazi Duha, ona postaje izliječena. U tome trenutku bolesni i razjedinjeni udovi dolaze zajedno, u istoj potrebi okupljaju se oko Glave - Krista i Izvorišta - Duha. I tako u zajedništvu oko Krista i snage Duha ostvaruje se pravo jedinstvo i poštivanje onih koji su u nekoj mjeri drukčiji od nas, naše subraće kršćana. Tek u pravom jedinstvu s Kristom, snagom Duha i ostalim udovima Kristova tijela ostvaruje se autentičan kršćanski identitet i Crkva je spremna otvoriti se prema onima koji su dublje drukčiji od nas.

$\mathrm{Na}$ te zaključke ukazali smo analizom biblijskoga teksta iz Dj 2, 1-13. Tamo nalazimo kako je prvotna kršćanska zajednica živjela autentičan kršćanski identitet kroz zajedništvo s Kristom u snazi Duha. Naši zaključci ukazuju kako je autentičan kršćanski identitet vidljiv u zajednici onih koji čekaju na Boga (Dj 1, 4); u zajednici onih koji su po istoj potrebi okupljeni zajedno oko Krista kao izvora snage (Dj 2, 1); u takvoj zajednici nazočan je živi Isus Krist koji, izlijevajući svoga Duha, 
osposobljava zajednicu za službu naviještanja silnih djela Božjih ( Dj 2, 4); takva je zajednica vjerna svom identitetu u Kristu kroz služenje drugima i drukčijima: svi narodi pod nebom čuju naviještaj o Bogu $(\mathrm{Dj} 2,5)$; u susretu s drugima zajednica je otvorena za specifične identitete drugih (ona govori njihovim jezicima), ali u toj otvorenosti ne gubi svoj identitet (drugi prepoznaju njezin identitet) ( $\mathrm{Dj} 2,6-8)$; zajednica naviješta silna djela Božja i nije zaokupljena sobom, već navještajem o Bogu (Dj 2, 11); njezin je govor otvoren poziv bez prisile. Svatko tko sluša ima pravo izbora prihvatiti poruku o Bogu ili poći svojim putem ( $\mathrm{Dj} 2,12-13)$.

$\mathrm{Na}$ taj način, živeći svoj autentičan identitet, Crkva postaje Božjim instrumentom po kojem sam Bog izražava svoju gostoljubivost svakom čovjeku na zemlji. Ta gostoljubivost nije puka retorika u kojoj bi netko izgubio dio sebe otvarajući se drugima, već, naprotiv, otkrivenje kako je u Kristu, po snazi Duha, Bog pripremio mjesto za sve naše različitosti koje u Njemu dosežu svoj puni smisao i potencijal. 


\title{
CHRISTIAN IDENTITY IN OPENNESS TO THE OTHERS AND THE DIFFERENT
}

\author{
David KOVAČEVIĆ*
}

Summary: The aim of this paper is to point to the specific source of Christian identity that allows for authentic proclamation of the mighty deeds of God. This source is the person of Jesus Christ who as a true man lived his life for others. It is this reality of the $\gg$ me and you $<$ relationship that should be the source of Christian identity and the way Christians relate to the others and the different. The Christian identity today is in crisis because Christian communities are generally taking a defensive position toward the challenges of the modern world and thereby extinguish the natural openness of the Christ's Gospel to the burdened world. In the paper, the author tries to portray the paradigm of the early Christian community as it is presented in the Book of Acts 2:1-13. In this biblical text, the early Christian community based their relationship toward others on their identity that stemmed from their relationship with the living Christ. This is evident in the following characteristics of the early Christian community: first of all they are waiting for the power from the high - the Holy Spirit; understanding the need for this power unites them - they are gathered together; when they are filled with the expected power of the Holy Spirit they are equipped for the ministry of proclaiming the mighty deeds of God; equipped this way, they are serving the others and the different - all nations under the heaven; they are open to the specific identities of others - but in this openness they are not losing their own identity; they are not preoccupied with themselves but with proclaiming God; and finally, the proclamation of God remains an invitation open to everyone, without coercion. A community that lives such an authentic Christian identity becomes God's instrument in the world through which God expresses his hospitality to every person on earth.

Keywords: identity, other and different, Jesus Christ, Pentecost, Holy Spirit, Christian community.

\footnotetext{
* David Kovačević, M. Sc., Evangelical Theological Seminary, Cvjetkova 32, 31000 Osijek, Croatia, david.kovacevic.cog@gmail.com
} 